\title{
PENGARUH RETURN SAHAM, VOLUME PERDAGANGAN SAHAM DAN VARIAN RETURN SAHAM TERHADAP BID-ASK SPREAD SAHAM PADA PERUSAHAAN MANUFAKTUR YANG TERGABUNG DALAM INDEKS LQ 45 PERIODE TAHUN 2003-2005
}

\author{
Sri Dwi Ari Ambarwti \\ Fakultas Ekonomi UPN “Veteran” Yogyakarta \\ E-mail: ambarwat73@yahoo.com
}

\begin{abstract}
The objective of this research is to test the impact of stock return, stock trading volume and variance of stock return toward bid-ask spread. Using sampling of 20 manufacture companies which are united in LQ 45 index during the period of 2003 until 2005. The compilation of data is done in Jakarta Stock Exchange corner UII, and Indonesian Capital Market Directory (ICMD). The analysis is done with multiple linear regression method, regretted classical assumption examined, $f$ - test and $t$-test.

The result shows that the hypothesis of stock return are rejected, in this result shows that stock return have a positive significant impact toward bid-ask spread while the hypothesis of stock trading volume and variance of stock return are accepted, in this result shows that stock trading volume has a negative significant impact toward bid-ask spread and variance of stock return has a positive significant impact toward bid-ask spread. While as it simultaneously show that stock return, stock trading volume, and variance of stock return have significantly impact toward bid-ask spread and variance of stock return have dominant impact.
\end{abstract}

Key words: Bid-ask spread, multiple linear regression method, stock trading volume, stock return, variance of stock return.

\section{PENDAHULUAN}

Pemain saham atau investor perlu memiliki sejumlah informasi yang berkaitan dengan dinamika harga saham agar bisa mengambil keputusan tentang saham perusahaan yang layak untuk dipilih. Sebenarnya hampir semua investasi mengandung unsur ketidakpastian atau risiko. Pemodal tidak tahu dengan pasti hasil yang akan diperoleh dari investasi yang dilakukannya. Dalam keadaan semacam ini dikatakan bahwa pemodal tersebut menghadapi risiko dalam investasi yang dilakukannya. (Suad Husnan, 1998).

Penilaian saham secara akurat bisa meminimalkan risiko sekaligus membantu investor mendapatkan keuntungan yang wajar, mengingat investasi saham di pasar modal merupakan jenis investasi yang cukup berisiko tinggi meskipun menjanjikan keuntungan yang relatif besar. Kelaziman yang sering dijumpai adalah bahwa semakin besar return yang diharapkan (expected), semakin besar pula peluang risiko yang terjadi.

Pengetahuan tentang bid-ask spread sangat perlu bagi investor terutama yang mengharapkan memperoleh capital gain, karena hal ini dipandang sebagai salah satu komponen biaya dalam perdagangan saham. Dalam penelitiannya, Kim dan Ismail (1996) menggunakan variabel bid-ask spread ini sebagai ukuran biaya informasi. Bid-ask spread merupakan selisih antara bid price dengan ask price. Bid price adalah harga 
tertinggi yang ditawarkan oleh dealer atau harga dimana spesialis atau dealer menawar untuk membeli saham, sedangkan ask price adalah harga terendah dimana dealer bersedia untuk menjual saham. Menurut Stoll (2000) dalam Barbara Gunawan dan Yulia Indah (2005), menyatakan bahwa bidask spread merupakan fungsi dari tiga komponen biaya yang berasal dari Inventory holding cost, Order processing cost dan Adverse information cost.

Biaya pemilikan sekuritas terdiri dari risiko harga dan opportunity cost yang dihubungkan dengan pemilikan saham. Biaya pemrosesan berhubungan dengan biaya untuk mengatur perdagangan, pencatatan transaksi, administrasi, telepon dan sebagainya. Sedangkan biaya informasi adalah biaya timbul karena adanya informasi asimetri para pelaku pasar modal. Informasi asimetri timbul karena adanya informasi yang tidak dapat didistribusikan secara merata kepada semua pelaku di pasar modal. Dalam hal ini dealer sebagai partisipan pasar modal, besarnya ketidakseimbangan informasi yang dihadapi dealer akan tercermin pada spread. Oleh karena itu, dealer selalu berusaha menentukan spread secara wajar dengan mempertimbangkan kejadian tertentu atau kondisi informasi lainnya sehubungan dengan sekuritas yang dimiliki.

Stoll (1989) dalam abdul dan Nasuhi (2000) menyatakan bahwa biaya pemilikan berpengaruh positif terhadap bid-ask spread. Artinya semakin tinggi biaya pemilikan akan menyebabkan semakin lebar bid-ask spread saham tersebut. Perdagangan surat berharga yang aktif yaitu dengan volume perdagangan yang besar, menunjukkan bahwa saham tersebut digemari oleh para investor. Kondisi seperti itu akan mendorong dealer untuk tidak memiliki saham dalam jangka waktu yang lama sehingga akan menurunkan biaya pemilikan. Jadi semakin aktif perdagangan suatu saham atau semakin besar volume perdagangan maka dengan sendirinya akan makin rendah biaya pemilikan yang nantinya akan berdampak pada semakin kecilnya bid-ask spread.

Studi Chan dan Seow maupun Miller (1998) dalam Abdul dan Nasuhi (2000), memberikan bukti empiris mengenai pengaruh negatif harga saham terhadap bidask spread saham. Berdasarkan penelitian terdahulu tentang bid-ask spread yang ada di latar belakang masalah ini, diperoleh hasil yang berbeda-beda. Oleh karena itu, peneliti ingin meneliti kembali konsistensi pengaruh dari return saham, volume perdagangan saham dan varian return saham terhadap bid-ask spread. Perbedaan dari peneliti sebelumnya terletak pada tahun penelitian dan objek penelitian. Alasannya peneliti ingin mengetahui kekonsistenan dari bid-ask spread pada perusahaan manufaktur untuk tahun 2003-2005.

Permasalahan yang akan dibahas dalam penelitian ini adalah 1) Apakah return saham mempunyai pengaruh terhadap bidask spread saham pada perusahaan manufaktur yang tergabung dalam indeks LQ 45 selama periode tahun 2003-2005?, 2) Apakah volume perdagangan saham mempengaruhi bid-ask spread saham pada perusahaan manufaktur yang tergabung dalam indeks LQ 45 selama periode tahun 20032005 ? dan 3) Apakah varian return saham mempengaruhi bid-ask spread saham pada perusahaan manufaktur yang tergabung dalam indeks LQ 45 selama periode tahun 2003-2005?

Manfaat penelitian adalah menambah referensi bagi ilmu pengetahuan di bidang manajemen keuangan dan dapat memberikan suatu kajian sebagai bahan pertimbangan bagi investor yang akan bertransaksi di pasar modal Indonesia, dengan adanya informasi mengenai return, volume perdagangan dan varian return saham diharapkan dapat dijadikan sebagai bahan untuk mengambil kebijaksanaan dalam strategi investasi. 


\section{TINJAUAN PUSTAKA \\ Landasan Teori \\ Pasar modal efisien}

Efficient Market atau pasar yang efisien merupakan suatu pasar bursa dimana efek yang diperdagangkan merefleksikan semua informasi yang mungkin terjadi dengan cepat dan akurat (Robbet Ang 1997, 17). Konsep Efficient market ini menyatakan bahwa pemodal selalu memasukkan faktor informasi yang tersedia dalam keputusan mereka sehingga terefleksi pada harga yang mereka transaksikan. Jadi harga yang berlaku di pasar sudah tergantung faktor informasi tersebut. Harga suatu efek mengandung tiga faktor yaitu Merefleksikan informasi yang bersifat historis, Merefleksikan kejadian yang telah diumumkan tetapi belum dilaksanakan seperti saham bonus, tetapi pembagian saham bonus belum dibagikan, dan merefleksikan prediksi atas informasi masa yang akan datang.

Menurut Jogiyanto (1998), bentuk efisiensi pasar dapat ditinjau tidak hanya dari segi ketersediaan informasinya saja, tetapi juga dapat dilihat dari kecanggihan pelaku pasar dalam pengambilan keputusan berdasarkan analisis dan informasi yang tersedia. Pasar efisien yang ditinjau dari sudut informasi saja disebut efisiensi pasar secara informasi (informationally efficient market). Sedangkan pasar efisien yang ditinjau dari sudut kecanggihan para pelaku pasar dalam mengambil keputusan berdasarkan informasi yang tersedia disebut dengan efisiensi pasar secara keputusan atau decisionally efficient market.

\section{Efisiensi Pasar Secara Informasi}

Kunci utama untuk mengukur pasar modal yang efisien adalah hubungan antara harga sekuritas dengan informasi. Dimana informasi yang dapat digunakan untuk menilai pasar yang efisen adalah informasi yang lama, informasi yang sedang dipublikasikan atau semua informasi termasuk informasi privat. Fama dalam Jogiyanto (1998), menyajikan tiga macam bentuk utama dari efisiensi pasar berdasarkan ketiga macam bentuk informasi, yaitu:

\section{Efisiensi pasar bentuk lemah (weak form)}

Pasar dikatakan efisien dalam bentuk lemah, jika harga-harga dari sekuritas tercermin secara penuh (fully reflect) informasi masa lalu. Informasi masa lalu ini merupakan informasi yang sudah terjadi. Bentuk efisiensi pasar secara lemah ini berkaitan dengan teori langkah acak (random walk theory) yang menyatakan bahwa data masa lalu tidak berhubungan dengan nilai sekarang. Jika pasar efisien secara bentuk lemah, maka nilai-nilai masa lalu tidak dapat digunakan untuk memprediksi harga sekarang. Ini berarti bahwa untuk pasar yang efisien bentuk lemah, investor tidak dapat menggunakan informasi masa lalu untuk mendapatkan keuntungan yang tidak normal.

\section{Efisiensi pasar bentuk setengah kuat (semistrong form) \\ Pasar dikatakan efisien setengah} kuat, jika harga-harga sekuritas secara penuh mencerminkan (fully reflect) semua informasi yang dipublikasikan (all publicly available information) termasuk informasi yang berada di laporan-laporan keuangan perusahaan emiten. Semua informasi yang dipublikasikan akan tersebar dan diterima oleh pemodal pada waktu yang hampir bersamaan, sehingga harga secara langsung dan cepat melakukan penyesuaian dan investor tidak mendapatkan keuntungan yang normal. Informasi yang dipublikasikan antara lain:

1) Informasi yang mempengaruhi harga sekuritas dari perusahaan yang mempublikasikan informasi tersebut. Informasi yang dipublikasikan ini merupakan informasi dalam bentuk pengumuman oleh perusahaan emiten. 
Informasi ini umumnya berhubungan dengan peristiwa yang terjadi di perusahaan emiten. Misalnya seperti pengumuman laba, pengumuman pembagian dividen, pengumuman pengembangan produk baru, pengumuman merjer dan akuisisi, dan lain sebagainya.

2) Informasi yang mempengaruhi hargaharga sekuritas sejumlah perusahaan. Informasi yang dipublikasikan ini dapat berupa peraturan pemerintah atau peraturan dari regulator yang hanya berdampak pada harga sekuritas perusahaan-perusahaan yang terkena regulasi tersebut. Misalnya seperti regulasi untuk meningkatkan kebutuhan cadangan yang harus dipenuhi oleh semua bank. Informasi ini akan mempengaruhi secara langsung harga sekuritas tidak sebuah bank saja, tetapi mungkin semua emiten di dalam industri perbankan.

3) Informasi yang mempengaruhi harga sekuritas semua perusahaan yang terdaftar di pasar saham. Informasi ini dapat berupa peraturan pemerintah atau peraturan dari regulator yang berdampak ke semua perusahaan emiten. Contoh regulasi adalah peraturan akuntansi untuk mencantumkan laporan arus kas yang harus dilakukan oleh semua perusahaan. Regulasi ini akan mempunyai dampak pada harga sekuritas tidak hanya untuk sebuah perusahaan saja atau perusahaan-perusahaan di suatu industri, tetapi mungkin berdampak langsung pada semua perusahaan.

\section{Efisiensi pasar bentuk kuat ( strong form )}

Pasar dikatakan efisien dalam bentuk kuat jika harga-harga sekuritas secara penuh mencerminkan (fully reflect) semua informasi yang tersedia termasuk informasi privat. Jika pasar efisien dalam bentuk ini berhubungan satu dengan yang lain, maka tidak ada individual investor atau grup dari investor yang dapat memperoleh keuntungan tidak normal (abnormal return) karena mempunyai informasi privat.

Salah satu jenis informasi privat adalah jenis informasi yang berasal dari orang dalam (insider information) yang mempunyai akses atas informasi berharga mengenai keputusan penting yang telah direncanakan oleh perusahaan. Sehingga dengan modal informasi tersebut mereka melakukan analisa dan mengambil posisi transaksi yang sesuai. Pada saat mengumumkan perseroan tersebut dikeluarkan, maka informasi tersebut menjadi tersedia bagi masyarakat dan akan mendongkrak harga saham tersebut. Informasi privat yang demikian mampu memberikan keuntungan abnormal yang konsisten bagi para pemodal yang memiliki informasi tersebut.

\section{Pengaruh Return Saham terhadap bid- ask spread}

Semakin besar risiko suatu sekuritas, semakin besar return yang diharapkan. Sebaliknya juga semakin kecil return yang diharapkan, semakin kecil pula risiko yang harus ditanggung. Hubungan positif ini hanya berlaku untuk return ekspektasi atau ex-ante return (before the fact), yaitu untuk return yang belum terjadi. Untuk return realisasi (yang sudah terjadi). Hubungan positif ini dapat tidak terjadi.

Demetz (1968, dalam Marwan Asri) berpendapat bahwa dealer memperoleh kompensasi dengan membeli saham pada harga beli $(\mathrm{Pb})$ yang umumnya lebih rendah dari harga sebenarnya dan menjual pada harga jual (Pj) diatas harga sebenarnya, $\mathrm{Pt}$ (true price). Spread yang diperoleh untuk menutup cost yang terjadi. Menurut Soll (1978) spread dapat dihitung dengan $(\mathrm{Pj}-$ $\mathrm{Pb}) / \mathrm{Pt}$. Dengan demikian spread akan semakin rendah bila harga saham (return) tinggi, atau dengan kata lain return berpengaruh negatif terhadap spreads. 
Pengaruh Varian Return Saham terhadap bid-ask spread

Varians return dalam hal ini mewakili risiko saham yang disinyalir dapat mempengaruhi besar kecilnya bid-ask spread saham. Varian return saham mewakili risiko saham yang dihadapi oleh dealer. Risiko saham yang semakin tinggi menyebabkan dealer berusaha menutupnya dengan spread yang lebih besar. Argumen ini didukung oleh hasil penelitian Branch dan Freed maupun Stoll (1978) dalam Magdalena Nany dan M. Abdul Aris (2004) yang menunjukkan bahwa varian return saham berhubungan positif dengan bid-ask spread.

\section{Volume Perdagangan Saham}

Volume perdagangan diartikan sebagai jumlah lembar saham yang diperdagangkan pada hari tertentu (Abdul dan Nasuhi, 2000). Perdagangan suatu saham yang aktif, yaitu dengan volume perdagangan yang besar, menunjukkan bahwa saham tersebut digemari oleh para investor yang berarti saham tersebut cepat diperdagangkan. Ada kemungkinkan dealer akan mengubah posisi kepemilikan sahamnya pada saat perdagangan saham semakin tinggi atau dealer tidak perlu memegang saham dalam jumlah terlalu lama. Volume perdagangan akan menurunkan kos pemilikan saham sehingga menurunkan spread. Dengan demikian semakin aktif perdagangan suatu saham atau semakin besar volume perdagangan suatu saham, maka semakin rendah biaya pemilikan saham tersebut yang berarti akan mempersempit bid-ask spread saham tersebut.

\section{Teori Spread}

Teori mengenai spread tidak terlepas oleh adanya aktivitas yang dilakukan oleh anggota bursa yang dapat mempengaruhi besarnya transaksi sekuritas di pasar modal. Berdasarkan Undang-Undang Pasar Modal
No. 8 tahun 1995 dan Peraturan Pemerintah RI No. 45 tahun 1995, perusahaan efek adalah pihak yang melaksanakan kegiatan adalah penjamin emisi efek (PPE), Perantara pedagang efek (PPE) dan Manajer ivestasi (MI).

Dengan demikian maka penelitian tentang spread lebih dihubungkan secara erat dengan PPE (dealer) daripada dengan perantara investasi (broker). Dealer adalah pihak yang dalam pelaksanaan transaksi jual beli sekuritas atau saham, mempunyai andil yang besar dalam pasar modal. Banyak hal yang telah dealer lakukan agar proses transaksi dapat berjalan dengan baik dan lancar.

Dalam perdagangan sekuritas investor yang berkeinginan untuk membeli dan atau menjual sesuai dengan harga dan jumlah yang diinginkan tidaklah selalu memperoleh harapan tersebut secara simultan. Keinginan investor tersebut terealisir dalam waktu cukup lama pada harga pasar yang sebenarnya Oleh karena market maker baik dealer atau broker mengatasi adanya ketidaksamaan waktu tersebut terhadap order yang dihadapi investor. Dealer dan broker dapat dikatakan sebagai perantara perdagangan sekuritas yang dilakukan individu secara tidak langsung. Broker akan melakukan transaksi atas nama investor untuk mendapatkan komisi. Sedangkan dealer akan melaksanakan transaksi untuk memperoleh keuntungan sendiri. Market maker tersebut memperoleh kompensasi karena aktivitas membeli dilakukan pada saat harga beli (bid price) lebih rendah daripada true price dan menjual saham pada saat harga jual (ask price) lebih tinggi daripada true price. Perbedaan harga ini disebut bidask spread, (Stoll, 1989).

Abdul dan Nasuhi (2000) mendefinisikan bid-ask spread sebagai selisih harga beli teringgi yang dealer bersedia membeli saham dengan harga jual terendah yang dealer bersedia menjual. 
Menurut Hamilton (dalam Esther, 1999) menyatakan ada dua model spread yaitu dealer spread dan market spread. Dealer spread merupakan selisih harga bid dan harga ask yang menyebabkan dealer ingin memperdagangkan sekuritas dengan aktivitas sendiri, sedangkan market spread adalah selisih highest bid dan lower ask yang terjadi pada saat tertentu. Oleh karena itu, kedua spread itu tidak dapat saling menggantikan. Spread yang diketahui ada di Bursa Efek Jakarta (BEJ) adalah market spread. Hal ini disebabkan aktivitas BEJ lebih bersifat competitives order matching market atau dikenal dengan order-driven market system dimana investor hanya dapat diperbolehkan menyerahkan order jual beli dan melakukan transaksi melalui broker. Investor tidak bisa langsung bertransaksi di lantai bursa.

\section{Penelitian Terdahulu}

Sukardi (2003) meneliti tentang pengaruh volume perdagangan dan return terhadap bid-ask spread saham pada perusahaan jasa telekomunikasi di Bursa Efek Jakarta. Esther (1999) meneliti tentang perubahan bid-ask spread dan return varian saham pasca stock split. Abdul dan Nasuhi (2000) meneliti tentang pengaruh volume perdagangan dan return terhadap bid-ask spread saham dari tiga perusahaan rokok yang aktif dan liquid pada tahun 1996-1998 menggunakan model koreksi kesalahan.

Magdalena Nany dan M. Abdul Aris (2004) meneliti tentang pengaruh harga saham, return saham, varian return saham, earnings dan volume perdagangan saham terhadap bid-ask spread pra dan pasca pengumuman laporan keuangan baik dalam kondisi good news maupun bad news. Barbara Gunawan dan Yulia Indah (2005) meneliti tentang pengaruh volume perdagangan dan return terhadap bid-ask spread dengan model koreksi kesalahan. Hasil penelitiannya menunjukkan bahwa varian return saham berpengaruh positif namun tidak signifikan terhadap bid-ask spread pra pengumuman laporan keuangan dalam kondisi good news, sedangkan varian return saham berpengaruh positif secara signifikan terhadap bid-ask spread pasca pengumuman laporan keuangan dalam kondisi good news. Volume perdagangan saham juga berpengaruh positif namun tidak signifikan terhadap bid-ask spread pra pengumuman laporan keuangan baik dalam kondisi good news maupun bad news, sedangkan volume perdagangan saham berpengaruh positif secara signifikan terhadap bid-ask spread pasca pengumuman laporan keuangan baik dalam kondisi good news maupun bad news. Sehingga dapat dirumuskan hipotesis sebagai berikut:

$\mathrm{H}_{1}$ : Return saham berpengaruh negatif terhadap bid-ask spread saham pada perusahaan manufaktur yang tergabung dalam indeks LQ 45 selama periode tahun 2003-2005.

$\mathrm{H}_{2}$ : Volume perdagangan berpengaruh negatif terhadap bid-ask spread saham pada perusahaan manufaktur yang tergabung dalam indeks LQ 45 selama periode tahun 2003-2005.

$\mathrm{H}_{3}$ : Varian return saham berpengaruh positif terhadap bid-ask spread saham pada perusahaan manufaktur yang tergabung dalam indeks LQ 45 selama periode tahun 2003-2005.

\section{METODE PENELITIAN Sampel Penelitian}

Untuk pengambilan sampel dalam penelitian ini digunakan metode purposive sampling, yaitu penentuan sampel dengan pertimbangan atau kriteria tertentu. Kriteria yang mendasarkan dipilihnya sampel penelitian ini adalah:

a. Perusahaan-perusahaan manufaktur yang termasuk dalam kelompok saham LQ 45 selama periode pengamatan tahun 2003-2005. 
b. Perusahaan-perusahaan manufaktur tersebut mempunyai closing price (harga saham), data bid-ask price (penutupan bid-ask), dan volume perdagangan selama periode pengamatan tahun 20032005.

Setelah dilakukan pengambilan sampel berdasarkan kriteria di atas maka didapatkan sampel sebanyak 20 perusahaan manufaktur yang tergabung dalam indeks LQ 45 selama periode tahun 2003-2005. Sumber data dalam penelitian ini diperoleh langsung dari Indonesian Capital Market Directory (ICMD) tahun 2003-2005, Fact Book, JSX Statistic, laporan BEJ, dan literaturnya.

\section{Variabel Penelitian}

Studi ini menggunakan alternatif variabel dependend berupa bid-ask spread relatif, yang dirumuskan sebagai berikut:

$$
\text { RBAt }=\frac{\left(\mathrm{HA}_{\mathrm{t}+1}-\mathrm{HB}_{\mathrm{t}+!}\right) \times 100 \%}{1 / 2\left(\mathrm{HA}_{\mathrm{t}+1}+\mathrm{HB}_{\mathrm{t}+1}\right) \times 100 \%}
$$

Keterangan :

BA $_{\mathrm{t}}=$ Bid-ask spread pada hari ke $\mathrm{t}_{+1}$

$\mathrm{HA}_{\mathrm{t}} \quad=$ Harga ask pada hari ke $\mathrm{t}_{+1}$

$\mathrm{HB}_{\mathrm{t}}=$ Harga bid pada hari ke $\mathrm{t}_{+1}$

$\mathrm{RBA}_{\mathrm{t}}=$ Bid-ask spread relatif pada hari ke $\mathrm{t}$

Variabel independen pertama yang digunakan adalah return $\left(\mathrm{R}_{\mathrm{t}}\right)$, yang didefinisikan sebagai perubahan relatif harga saham dari periode sebelumnya (Jogiyanto, 2000), yang dirumuskan sebagai berikut:

$\mathrm{R}_{\mathrm{t}}=\frac{\left(\mathrm{P}_{\mathrm{t}}-\mathrm{P}_{\mathrm{t}-1}\right) \mathrm{x} 100 \%}{\mathrm{P}_{\mathrm{t}-1}}$

Keterangan:
$\mathrm{R}_{\mathrm{t}}=$ Return saham pada hari ke- $\mathrm{t}$

$\mathrm{P}_{\mathrm{t}} \quad$ = Harga penutupan saham pada hari ke (t)

$\mathrm{P}_{\mathrm{t}-1}=$ Harga penutupan saham pada hari ke (t-1)

Sebagai alternatif dari variabel $R_{t}$ dapat diganti dan dibandingkan dengan variabel harga penutupan saham pada hari ke t. $\left(\mathrm{P}_{\mathrm{t}}\right)$. Sedangkan, Volume perdagangan $\left(\mathrm{V}_{\mathrm{t}}\right)$ merupakan variabel independen kedua di dalam penelitian ini, yang didefinisikan sebagai jumlah lembar saham yang diperdagangkan pada hari ke t. Variabel ketiga yang digunakan adalah varian return saham yang dalam hal ini mewakili risiko saham (PPA UGM, 2001), yang dirumuskan sebagai berikut:

$$
\begin{aligned}
& \text { VARTOTRAHDT }= \\
& \frac{\sum_{\mathrm{i}=\mathrm{t}}^{\mathrm{a}}\left(\mathrm{RETH}_{\mathrm{i}}-\mathrm{RATARAHDT}^{2}\right.}{\mathrm{n}}
\end{aligned}
$$

Keterangan :

RATARAHDT $=$ Rata-rata aritmatika return harian dalam tahun

$\mathrm{a}=$ awal periode, yaitu mulai 1 januari tahun XXXX

$t=$ Tanggal hari efektif tahun $\mathrm{XXXX}$

$\mathrm{n}=$ Jumlah hari

\section{HASIL DAN ANALISIS PENELITIAN \\ Hasil Dan Analisis Regresi Linear Berganda}

Berdasarkan proses pengolahan data, hasil regresi yang didapatkan adalah sebagai berikut (lihat Tabel 1). 
Jurnal Siasat Bisnis Vol. 12 No. 1, April 2008 Hal: 27 - 38

Tabel 1. Hasil Regresi Linear Berganda Pada Perusahaan Manufakur Yang Tergabung dalam Indeks LQ 45 Periode 2003-2005

\begin{tabular}{lcccc}
\hline Variabel bebas & Koefisien Regresi & t hitung & Probabilitas & Keterangan \\
\hline Constant & 0,002045 & 26,524 & 0,000 & Signifikan \\
Return saham (X1) & 0,002189 & 11,771 & 0,000 & Signifikan \\
Volume perdagangan saham (X2) & $-0,000052$ & $-16,004$ & 0,000 & Signifikan \\
Varian return (X3) & 0,906371 & 309,668 & 0,000 & Signifikan \\
$\mathrm{R}^{2}$ & 0,985 & & & \\
$\mathrm{~F}$ & 47014,572 & & & Signifikan \\
Probabilitas & 0,000 & & & \\
\hline
\end{tabular}

Adapun secara matematis model regresinya tamapk sebagai berikut:

Bid-ask Spread = 0,002045 + 0,002189RET - 0,000052VOL $+0,906371 \mathrm{VAR}$

Berdasarkan model regresi di atas, maka dapat dikemukakan bahwa konstanta sebesar 0,002045 menunjukkan bahwa jika variabel return saham, volume perdagangan, dan varian return saham dianggap konstan maka rata-rata bid-ask spread saham perusahaan manufaktur yang dijadikan objek dalam penelitian ini adalah sebesar 0,002045\%, variabel return saham mempunyai pengaruh positif terhadap bid-ask spread saham karena memiliki koefisien regresi sebesar 0,002189 dengan nilai probabilitas sebesar 0,000. Angka koefisien tersebut memiliki arti bahwa apabila return saham naik sebesar 1\%, maka diharapkan bid-ask spread juga meningkat sebesar 0,002189\%, demikian juga sebaliknya, Variabel volume perdagangan saham mempunyai pengaruh negatif terhadap bid-ask spread saham karena memiliki koefisien regresi sebesar-0,000052 dengan nilai probabilitas sebesar 0,000. Angka koefisien tersebut memiliki arti bahwa apabila volume perdagangan saham naik sebesar $1 \%$, maka diharapkan bid-ask spread juga meningkat sebesar 0,000052\%, demikian juga sebaliknya. Kemudian variabel varian return saham mempunyai pengaruh negatif terhadap bid- ask spread saham karena memiliki koefisien regresi sebesar 0,906371 dengan nilai probabilitas sebesar 0,000. Angka koefisien tersebut memiliki arti bahwa apabila varian return saham naik sebesar 1\%, maka diharapkan bid-ask spread juga meningkat sebesar 0,906371\% atau sebaliknya.

Berdasarkan tabel 1 di atas dapat dijelaskan bahwa ketiga variabel bebas yaitu return saham $\left(\mathrm{X}_{1}\right)$, volume perdagangan saham $\left(\mathrm{X}_{2}\right)$ dan varian return saham $\left(\mathrm{X}_{3}\right)$ yang dimasukkan dalam model memiliki pengaruh yang signifikan terhadap bid-ask spread saham (Y). Hal ini dapat dilihat dari tingkat signifikansinya sebesar 0,000 lebih kecil dari $\alpha=0,05$.

\section{Uji Asumsi Dasar Klasik Regresi}

Setelah dilakukan uji dengan menggunakan asumsi dasar klasik regresi ternyata dianggap tidak terjadi gejala multikolinearitas ditunjukkan dengan nilai VIF ketiga variabel bebas dibawah 5, tidak terjadi gejala heteroskedastisitas ditunjukkan dengan korelasi antara residual dengan variabel bebas tidak signifikan, pada tingkat probabilitas diatas 0,05 dan tidak terjadi gejala autokorelasi yang ditunjukkan dengan nilai Durbin Watson 1,814 yang berada pada daerah tidak terjadi autokorelasi. Oleh karena itu model regresi tersebut dapat diteliti lebih lanjut. 
Hasil Uji Pengaruh Return Saham terhadap Bid-ask Spread

Berdasarkan tabel 1 dapat dilihat bahwa variabel Return saham, dengan menggunakan level of significant $\alpha=5 \%$ berpengaruh signifikan terhadap bid-ask spread saham karena memiliki tingkat signifikansi 0,000 yang lebih kecil dari taraf signifikansi 0,05. Variabel return saham memiliki koefisien regresi sebesar 0,002189 Hasil ini menunjukkan bahwa variabel return saham mempunyai pengaruh positif dan signifikan terhadap bid-ask spread saham. Dalam penelitian ini hipotesis yang diajukan adalah return saham berpengaruh negatif terhadap bid-ask spread saham pada perusahaan manufaktur yang tergabung dalam LQ 45 selama periode 2003-2005, namun dengan berdasarkan hasil penelitian yang diperoleh maka hal ini menunjukkan bahwa hipotesis pertama ditolak.

Pengaruh positif ini terjadi karena pergerakan saham manufaktur pada tahun 2003-2005 dapat dikatakan bahwa harga saham cenderung senantiasa naik dalam tiap transaksinya berarti menghasilkan return saham yang tinggi, hal ini mengindikasikan bahwa saham tersebut aktif diperdagangkan, dan dengan keadaan ini menunjukkan bahwa saham tersebut digemari oleh para investor. Keadaan ini juga senantiasa membuat dealer tidak langsung melepas saham tetapi saham tersebut di tahan terlebih dahulu sampai pada waktu tertentu, sehingga semakin lama saham tersebut berada di tangan dealer maka akan menimbulkan adanya bid-ask spread saham yang lebih besar karena akan menyerap lebih banyak biaya kepemilikan saham yang ditanggung oleh dealer. Hal ini terjadi karena dealer menganut motif jangka panjang dalam berinvestasi, dengan maksud yaitu untuk dapat menutup biaya transaksi yang terjadi untuk membeli saham tersebut. Maka dari itu hasil dari penelitian ini tidak menunjukkan adanya pengaruh negatif return saham terhadap bid-ask spread saham perusahaan manufaktur tahun 2003-2005. Hal ini menunjukkan bahwa hipotesis pertama ditolak.

Hasil penelitian ini konsisten dengan penelitian sebelumnya yang dilakukan oleh Barbara Gunawan dan Yulia Indah (2005) yang menyatakan bahwa return saham tidak menunjukkan adanya pengaruh negatif atau terbalik terhadap bid-ask spread saham.

\section{Hasil Uji Pengaruh Volume Perdagangan Saham terhadap Bid-ask Spread}

Berdasarkan tabel 1 dapat diketahui bahwa variabel volume perdagangan saham, dengan menggunakan level of significant $\alpha=5 \%$ berpengaruh signifikan terhadap bid-ask spread saham karena memiliki tingkat signifikansi 0,000 yang lebih kecil dari taraf signifikansi 0,05 . Variabel volume perdagangan saham memiliki koefisien regresi sebesar -0,000052. Hasil ini menunjukkan bahwa variabel volume perdagangan saham mempunyai pengaruh negatif dan signifikan terhadap bid-ask spread saham. Dalam penelitian ini hipotesis yang diajukan adalah volume perdagangan saham berpengaruh negatif terhadap bid-ask spread saham pada perusahaan manufaktur yang tergabung dalam LQ 45 selama periode 2003-2005, namun dengan berdasarkan hasil penelitian yang diperoleh maka hal ini menunjukkan bahwa hipotesis kedua diterima.

Variabel volume perdagangan saham, perhitungan terhadap volume perdagangan menunjukkan hasil bahwa koefisien volume perdagangan memiliki pengaruh negatif. Hal ini terjadi karena volume perdagangan mempunyai hubungan yang cukup kuat dengan harga saham, pergerakan harga saham manufaktur pada tahun 2003-2005 cenderung senantiasa naik dan memberikan return yang besar sehingga menyebabkan saham tersebut digemari oleh para investor, dan dengan sendirinya permintaan akan saham tersebut akan tinggi dengan tingginya 
permintaan, sehingga menghasilkan volume perdagangan saham yang aktif. keadaan ini menyebabkan dealer tidak perlu memegang saham terlalu lama/langsung melepas saham tersebut. Disini dealer menganut motif jangka pendek dalam berinvestasi, dengan maksud hanya untuk mendapatkan capital gain, sehingga jangka waktu dealer memegang saham berkurang yang mengakibatkan biaya kepemilikan turun dan bidask spread menyempit. Maka dari itu hasil dari penelitian ini menunjukkan adanya pengaruh negatif volume perdagangan saham terhadap bid-ask spread saham perusahaan manufaktur tahun 2003-2005. Hal ini menunjukkan bahwa hipotesis kedua diterima.

Hasil penelitian ini tidak konsisten dengan penelitian sebelumnya yaitu penelitian Barbara Gunawan dan Yulia Indah (2005) dan Sukardi (2003) yang menyatakan bahwa volume perdagangan terbukti tidak berpengaruh secara terbalik atau negatif terhadap bid-ask spread saham.

\section{Hasil Uji Pengaruh Varian Return terhadap Bid-ask Spread}

Berdasarkan tabel 1 dapat diketahui bahwa variabel Varian return saham, dengan menggunakan level of significant $\alpha$ $=5 \%$ berpengaruh signifikan terhadap bidask spread saham, karena memiliki tingkat signifikansi 0,000 yang lebih kecil dari taraf signifikansi 0,05. Variabel varian return saham memiliki koefisien regresi sebesar 0,906371. Hasil ini menunjukkan bahwa variabel varian return saham berpengaruh positif dan signifikan terhadap variabel bidask spread saham. Dalam penelitian ini hipotesis yang diajukan adalah varian return saham berpengaruh positif terhadap bid-ask spread saham pada perusahaan manufaktur yang tergabung dalam LQ 45 selama periode 2003-2005, namun dengan berdasarkan hasil penelitian yang diperoleh maka hal ini menunjukkan bahwa hipotesis ketiga diterima.
Variabel varian return saham, penelitian ini menunjukkan bahwa varian return saham mewakili risiko yang dihadapi oleh dealer. Risiko saham yang semakin tinggi, yang diakibatkan oleh pergerakan harga saham manufaktur tahun 2003-2005 senantiasa menyebabkan dealer berusaha menutupnya dengan spread yang lebih besar. Dapat dikatakan besarnya risiko saham manufaktur tahun 2003-2005 membuat dealer menahan saham tersebut terlebih dahulu sampai pada waktu tertentu sehingga biaya kepemilikan saham meningkat yang menyebabkan lebarnya spread yang ada. Maka dari itu hasil dari penelitian ini menunjukkan adanya pengaruh positif varian return saham terhadap bid-ask spread saham perusahaan manufaktur tahun 20032005 Hal ini menunjukkan bahwa hipotesis ketiga diterima.

Hasil penelitian ini konsiten dengan hasil penelitian yang dilakukan oleh Magdalena Nany dan M. Abdul Aris (2003) yang menyatakan bahwa varian return saham berpengaruh positif terhadap bid-ask spread.

\section{KESIMPULAN DAN SARAN Kesimpulan}

Dalam penelitian pada saham perusahaan manufaktur yang tergabung dalam indeks LQ 45 periode tahun 2003 2005, menunjukkan bahwa secara bersamasama return saham, volume perdagangan saham dan varian return saham mempunyai pengaruh yang signifikan terhadap bid-ask spread saham. Dengan R Square 0,985 hal ini berarti bahwa 98,5\% variasi dari spread bisa dijelaskan oleh ketiga variabel bebas sedangkan sisanya sebesar 1,5\% dijelaskan oleh variabel lain yang tidak dimasukkan dalam penelitian.

Variabel return saham dan varian return saham secara parsial mempunyai pengaruh yang positif dan signifikan terhadap bid-ask spread saham perusahaan 
manufaktur yang tergabung dalam indeks LQ 45 periode tahun 2003 -2005. Sedangkan variabel volume perdagangan saham secara parsial berpengaruh negatif dan signifikan terhadap bid-ask spread saham perusahaan manufaktur yang tergabung dalam LQ 45 periode tahun 2003 - 2005.

Varian return saham merupakan variabel bebas yang dominan mempengaruhi bid-ask spread perusahaan manufaktur yang tergabung dalam indeks LQ 45 periode tahun 2003 sampai dengan tahun 2005 karena memiliki koefisien beta yang paling besar.

\section{Saran}

Bagi investor atau calon investor yang hendak melakukan investasi di pasar modal hendaknya perlu menjadikan return saham, volume perdagangan saham dan varian return saham sebagai acuan dalam pengambilan keputusan investasi, karena secara simultan ketiga variabel tersebut mempunyai pengaruh yang signifikan terhadap perusahaan manufaktur yang tergabung dalam LQ 45 periode tahun 2003 sampai dengan 2005.

Untuk mendapatkan keuntungan yang diharapkan hendaknya investor atau calon investor mengetahui nilai dari return saham dan volume perdagangan, karena kedua variabel tersebut merupakan variabel yang secara parsial positif dan signifikan terhadap bid-ask spread saham.

Peneliti selanjutnya yang ingin membuat penelitian sejenis, hendaknya perlu dikembangkan dengan variabel lain yang disinyalir dapat mempengaruhi besarnya bid-ask spread saham seperti variabel jumlah dealer yang berkompetisi dan hari perdagangan saham. Begitu pula dengan sampel diharapkan mampu menambah/memperluas jumlah sampel perusahaan/industri, hal ini didasarkan agar hasil yang didapat lebih akurat dan bervariasi.

\section{DAFTAR PUSTAKA}

Abdul dan Nasuhi Hidayat, (2000), "Studi Empiris Tentang Pengaruh Volume Perdagangan Dan Return Terhadap Bid-Ask Spread Industri Rokok Di Bursa Efek Jakarta Dengan Model Koreksi Kesalahan”, Jurnal Riset Akuntansi Indonesia, Vol.3 No.1, Januari, Hal 69-85.

Agus Subardi, (1994), Manajemen Keuangan, Jilid 1, Penerbit UPP AMP YKPN, YogYakarta.

Algifari, (1997), Analisis Regresi, Edisi II, Penerbit BPFE, YogYakarta.

Bambang Riyanto, (1995), Dasar-Dasar Pembelanjaan Perusahaan, Edisi Keempat, BPFE UGM, Yogyakarta.

Barbara Gunawan dan Yulia Indah, (1995), "Studi Empiris Tentang Pengaruh Volume perdagangan Dan Return Terhadap Bid-Ask Spread Industri Farmasi Di Bursa Efek Jakarta Dengan Model Korelasi Kesalahan”, Jurnal Riset Akuntansi Dan Investasi, Vol.6 No.2, Juli, Hal 165-185.

Darmadji dan Hendry Fakhruddin, (2001), Pasar Modal di Indonesia: Pendekatan Tanya Jawab, Jakarta: Salemba Empat.

Fabozzi, Frank J., (1999), Manajemen Investasi, Buku satu, Penerbit Salemba Empat, Jakarta.

Gujarati Damodar, (1995), Ekonometrika Dasar, Penerbit Erlangga, Jakarta.

Gunawan Sumodinigrat, (1994), Ekonometrika Pengantar, Edisi pertama, BPFE UGM,Yogyakarta. 
, (2003, 2004, 2005), Indonesia Capital Market Directory, Institute For Economic Financial Research.

, (2001), Indonesian Sekuritas Market Database, Penerbit PPA UGM, YogYakarta.

James C. Van Horne dan John M. Wachowich Terjemahan Heru Sutojo, (1998), Prinsip-Prinsip Manajemen Keuangan, Buku satu, Edisi Bahasa Indonesia, Penerbit Salemba Empat, Jakarta.

J. Fred Weston Dan Thomas E., Copeland, (1995), Managemen Keuangan, Jilid 1, Edisi Kedelapan, Penerbit Erlangga.

Jogiyanto H.M., M.B.A., Teori Portofolio Dan Analisis Investasi, Edisi Kedua, Penerbit BPFE, Yogyakarta.

Lisse Indrawati Septikaningsih, (2006), "Pengaruh Harga, Volume Perdagangan, Dan Volatilitas Harga Saham Terhadap Bid-Ask Spread Pada Perusahaan Yang Melakukan Stock Split Di Bursa Efek Jakarta”, Skripsi Program Sarjana, Fakultas Ekonomi, Universitas Pembangunan Nasional, "Veteran" Yogyakarta, Tidak Dipublikasi.

Magdalena Nany dan M. Abdul Aris, (2004), 'Pengujian Stabilitas Struktural Pengaruh Harga Saham, Return Saham, Varian Return Saham Dan Volume Perdagangan Terhadap Bid-Ask Spread Pra Dan
Pasca Laporan Keuangan”, Empirika, Vol.17 No.1, Hal 40-49.

Piter Tedu Batauna, (1994), Mengenal Pasar Modal Dan Tata Aturan Perdagangan Efek Serta BentukBentuk Perusahaan Di Indonesia, Flores: Nusa Indah.

Robbert Ang, (1997), Buku Pintar Pasar Modal Indonesia, Penerbit Mediasoft Indonesia.

Sawidji Widyoatmojo, (1993), Cara Sehat Investasi di Pasar Modal: Pengetahuan Dasar, Penerbit Jurnalindo Aksara Grafika, Jakarta.

Soehardi Sigit, (2001), Pengantar Metodologi Penelitian, Edisi 2001, Penerbit BPFE, YogYakarta.

Sritua Arif, (1993), Metodologi Penelitian Ekonomi, Penerbit UI, Jakarta.

Suad Husnan, (1998), Dasar-Dasar Teori Portofolio Dan Analisis Sekuritas, Edisi III, Penerbit UPP AMP YKPN, YogYakarta.

Sugiyono, (2002), Metode Penelitian Bisnis, Penerbit CV. Alfabeta, Bandung.

Sukardi, (2003), "Pengaruh Volume Perdagangan Dan Return Terhadap Bid-Ask Spread Saham Pada Perusahaan Jasa Telekomunikasi Di Bursa Efek Jakarta”, Skripsi Program Sarjana, Fakultas Ekonomi, Universitas Pembangunan Nasional, "Veteran” Yogyakarta, Tidak dipublikasi. 